\title{
Traffic Flow Hypothetical Modelling for Air Quality Improvement and Planning Purposes
}

\author{
Iveta Steinberga \\ Faculty of Geography and Earth \\ Sciences \\ University of Latvia \\ Riga, Latvia \\ iveta.steinberga@lu.lv \\ Janis Bikse $\mathbf{J r}$ \\ Faculty of Geography and Earth Sci- \\ ences \\ University of Latvia \\ Riga, Latvia \\ bikshe.janis@gmail.com
}

\author{
Liene Sustere \\ Faculty of Geography and Earth Sci- \\ ences \\ University of Latvia \\ Riga, Latvia \\ liene.sustere@gmail.com \\ Janis Kleperis \\ Institute of Solid State Physics \\ Riga, Latvia \\ janis.kleperis@riga.lv
}

\author{
Janis Bikse \\ Vidzeme University of Applied Sciences \\ Cesis, Latvia \\ janis.bikshe@gmail.com
}

\begin{abstract}
The main emphasis of this research was to describe air pollution level and dispersion in a typical street canyon (Valdemara Street in Riga (Latvia) city centre), afterward to postulate potential development scenarios and perform modelling in order to understand the influence on air pollution level. For this purpose special mathematical model was used - Operational Street Pollution Model (OSPM), which was developed by the National Environmental Research Institute in Denmark. Following development scenarios were tested: (1) realistic environmentally friendly - decrease of traffic flow by $50 \%$, as according to street interviews about $36-50 \%$ of drivers are ready to change driving habits from car to bicycle; (2) strictly limited - "green light" for public transport, but restrictions for old private cars, flow speed limitations.
\end{abstract} flow.

Keywords—air quality, modelling, street canyons, traffic

\section{INTRODUCTION}

Transport, either private or public, is an integral part of civilization development. Besides with many other benefits, there are many negative aspects - traffic jams, air pollution, noise pollution, massive impact on buildings and vegetation. On the global and also European scale, on-road traffic is well known as one of the main sources of total air pollution within anthropogenic emission field. There is a tendency to introduce tighter emission control schemes and standards, work on air pollution improvement plans in order to reduce public health risks.

Many of previous studies on air quality in the built environment proves that air quality is still to be a primary health risk factor for major population in the world, for example about $54 \%$ of world population in 2014 was overexposed to very high air pollution in urban areas. Moreover, according to tendency analysis exposed population will increase even till $66 \%$ by 2050 [1] and traffic induced emissions are stated as the main air pollution source in cities and agglomerations around world [2, 3, 4]. Various activities concerning different green infrastructures in the urban environment has been has been offered for air quality improvement reasons and in order to develop sustainable city concept as well $[5,6,7]$. Mostly following green infrastructures were proposed: green walls or roofs, street trees, vegetation barriers which to be expected will influence dispersion and depositions processes of air pollutants, either gaseous or suspended [8,9]. Additionally some microclimatic improvements were expected as green infrastructures potentially may mitigate dangerous impact of heat wave [10]. Some of the researchers describes design of green infrastructures, unfortunately concluding that positive and even negative impacts can occur depending on vegetation specifics. While vegetation aspects are still unclear city planners mainly focuses on traffic flow modulation, speed limitations and some other related activities.

Street canyons are very specific, air pollution is usually trapped by buildings, so the importance of buildings and the shape of their roofs is very important. Before any activities dealing with traffic organization, it is preferable to explore in detail structural specifics of traffic flow, its tendency of movement and influence of meteorological factors.

In street canyons emissions from combustion are produced, mainly in form of nitrogen oxides, particulate matter and carbon monoxide, additionally non-exhaust emissions are possible from mechanical abrasion of brakes, tires and road surfaces. And, also secondary pollutants, mainly in form of particulate matter $\mathrm{PM}_{2.5}$, are produced in photochemical reactions between volatile organic compounds, nitrogen monoxide and tropospheric ground level ozone. 


\section{MATERIAL AND METHODS}

\section{A. Site and model description}

OSPM (Operational Street Pollution Model) mathematical model was used to estimate $\mathrm{NO}_{\mathrm{x}}$ and $\mathrm{PM}_{10}$ hourly concentrations in the street canyon of Valdemara Street (Riga, Latvia). This street canyon is busy and irregular as presented in Fig. 1 and 2, has four lanes, it is $20 \mathrm{~m}$ wide and orientated South-West to North-East. Buildings on both sides are $25 \mathrm{~m}$ high, traffic flow is approximately 52000 vehicles per day with a fraction of heavy vehicles about $2-5 \%$. Average traffic speed is around $30-40 \mathrm{~km} / \mathrm{h}$. Fig. 3 illustrates the diurnal variation of hourly average traffic flow for working days. Information on traffic flow, average road traffic speed, and vehicle fleet composition was obtained from local (Riga) municipality.

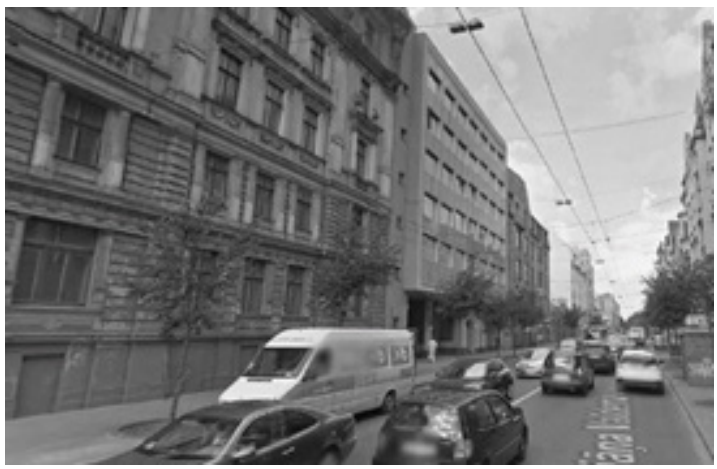

Fig. 1. Representation of study site, Google Map photography.

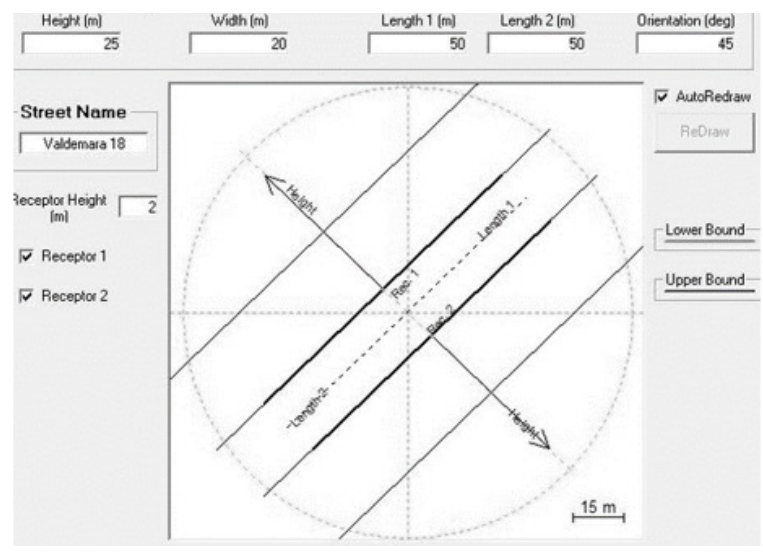

Fig. 2. Street geometry setting in OSPM model.

Used air quality model calculate pollutant concentrations and deposition fluxes using mathematical equations describing the atmospheric transport processes and chemical and physical transformation processes between the points of emissions and the receptor location(s). The main model input parameters in OSPM are summarized in Table 1.

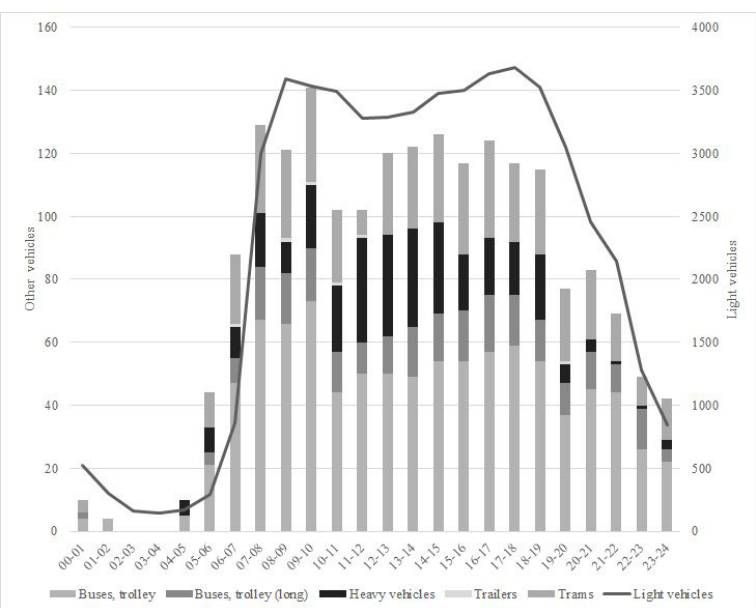

Fig. 3. Diurnal traffic flow in Valdemara Street during working day (April 21, 2010)

TABLE I. MODEL INPUT PARAMETERS

\begin{tabular}{|c|c|}
\hline Parameter & Description \\
\hline$\alpha$ & $\begin{array}{l}\text { Slope of emission dispersion plume. Proportion } \\
\text { between roof level wind speed and roof level } \\
\text { vertical turbulence. Element of denominator in } \\
\text { the calculation of chemical residence time. }\end{array}$ \\
\hline $\mathrm{c}$ & $\begin{array}{l}\text { Length of recirculation zone divided by the up- } \\
\text { wind building height for wind speeds higher than } \\
\text { g. }\end{array}$ \\
\hline $\mathrm{L}_{\mathrm{t}}$ & $\begin{array}{l}\text { Upper length of the recirculation trapezium di- } \\
\text { vided by the length of the baseline. }\end{array}$ \\
\hline d & $\begin{array}{l}\text { Angle of integration in radians for wind speeds } \\
\text { higher than } i \text {. }\end{array}$ \\
\hline$f_{\text {roof }}$ & $\begin{array}{l}\text { Scale factor to reduce the wind speed from a me- } \\
\text { teorological mast to roof level. }\end{array}$ \\
\hline $\mathrm{h}_{0}$ & Initial dispersion height in the wake of a car. \\
\hline $\mathrm{z}_{0}$ & $\begin{array}{l}\text { Aerodynamic roughness height used to relate } \\
\text { roof level wind to street level wind in a logarith- } \\
\text { mic profile. }\end{array}$ \\
\hline g & $\begin{array}{l}\text { Wind speed where the recirculation zone reaches } \\
\text { its full extent. }\end{array}$ \\
\hline $\mathrm{i}$ & $\begin{array}{l}\text { Upper limit for increased wind direction aver- } \\
\text { aging. }\end{array}$ \\
\hline $\mathrm{j}$ & $\begin{array}{l}\text { Upper limit of interval for which the general } \\
\text { building height is taken as the average. }\end{array}$ \\
\hline $\mathrm{H}_{\min }$ & Minimum general building height. \\
\hline $\mathrm{Sp}$ & Aerodynamic frontal area of light duty vehicles. \\
\hline St & $\begin{array}{l}\text { Aerodynamic frontal area of heavy-duty vehi- } \\
\text { cles. }\end{array}$ \\
\hline g & Scale factor for traffic produced turbulence. \\
\hline $\mathrm{k}$ & $\begin{array}{l}\text { Scale factor to reduce the impact of traffic pro- } \\
\text { duced turbulence at the top of the street canyon. } \\
\text { Element in the denominator in the calculation of } \\
\text { chemical residence time. }\end{array}$ \\
\hline$\gamma$ & $\begin{array}{l}\text { Scale factor for ground level wind speed reduc- } \\
\text { tion from parallel to perpendicular wind direc- } \\
\text { tions. }\end{array}$ \\
\hline
\end{tabular}

Following assumptions were taken in account:

(1) mathematical model consists of emissions calculated with COPERT IV methodology [11] and a dispersion model running in series. To limit the scope of the present study the focus was on the parameters related to the dispersion model. 
(2) resulting hourly average pollution concentrations of specific substances at the both sides of the street were evaluated. That was calculated as a sum of direct contribution $\left(\mathrm{C}_{\mathrm{dir}}\right)$ and recirculating contribution $\left(\mathrm{C}_{\mathrm{rec}}\right)$ plus background concentration.

(3) the direct contribution is modelled using a simplified Gaussian plume model with a top hat distribution applied to the emission plume. The recirculating contribution is modelled using a trapezium-shaped box model $[12,13,14]$.

(4) wind direction, especially for low wind speeds, cannot be assumed as constant over a full hour. To account for this, a numerical wind direction averaging procedure is implemented in the model [15].

(5) the model also contains an algebraic expression for traffic produced turbulence. The expression depends on the number of cars in the street, their respective driving speeds and traffic composition.

(6) most traffic pollutants are assumed to be inert on the time scale of the residence time in a street canyon.

Background concentration and meteorology input data are obtained from the Latvian Environment, Geology and Meteorology Centre and Riga city council monitoring programme. Intensity of traffic are mainly determinates by flow intensity on bridges, daily records during the period 2001-2014 shows that up to the year 2009 as a whole flow distribution are unchanged: average $44 \%$ of total flow crosses the Salu Bridge, $26-30 \%$ Vansu Bridge and Akmens Bridge (last two of them closely connected to city centre).

\section{B. Scenario description}

Based on a real (the year 2013) analysis several possible future traffic scenarios were analysed. To examine these cases, it was assumed that the meteorological conditions, the geometrical configuration of the street, traffic load and vehicle technology were identical to the values of 2013 . Following scenarios were estimated:

(1) SCEN1: restrictions for a light vehicle (private car) flow during working days from 7:00 AM to 7:00 PM;

(2) SCEN2: restrictions for old cars, the movement is allowed for EURO5 or higher standard light cars;

(3) SCEN3: light vehicle traffic is allowed only on holidays;

(4) SCEN4: light vehicle traffic is reduced by $50 \%$, just two of four lines is scheduled for passenger vehicles;

(5) SCEN5: light vehicle traffic is allowed only on holidays during winter, spring and autumn season, while during summer time no any restrictions are introduced.

\section{Results AND DISCUSSION}

Overall, modelling results were obtained for different traffic flows in typical cases; according to OSPM model guidelines, a total of 8 day-type cases were used where daily traffic flow hour-by-hour was described during working days and holidays in January-June and AugustDecember, additionally, 4 different cases were created for July as the most popular summer holiday month.

The most effective scenario for $\mathrm{PM}_{10}$ and $\mathrm{NO}_{\mathrm{x}}$ concentration decrease was identified as the second scenario (SCEN2: restrictions for old cars, movement is allowed for EURO5 or higher standard light cars), and according to results it could be expected that exhaust concentrations could decrease by $9 \mu \mathrm{g} / \mathrm{m}^{3}$ for $\mathrm{PM}_{10}$ and 90 $\mu \mathrm{g} / \mathrm{m}^{3}$ for $\mathrm{NO}_{\mathrm{x}}$ in average. Comparative representation of scenario results is shown in Fig. 4 and Fig. 5.

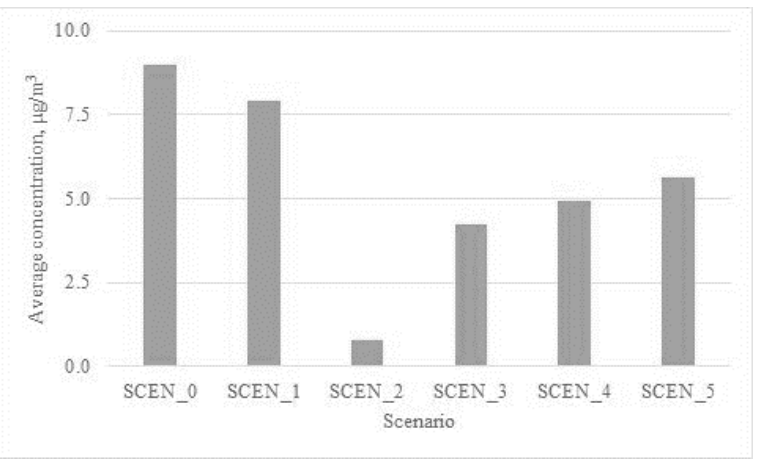

Fig. 4. Average modelled $\mathrm{PM}_{10}$ concentration at receptor height $(2 \mathrm{~m})$ in street canyon

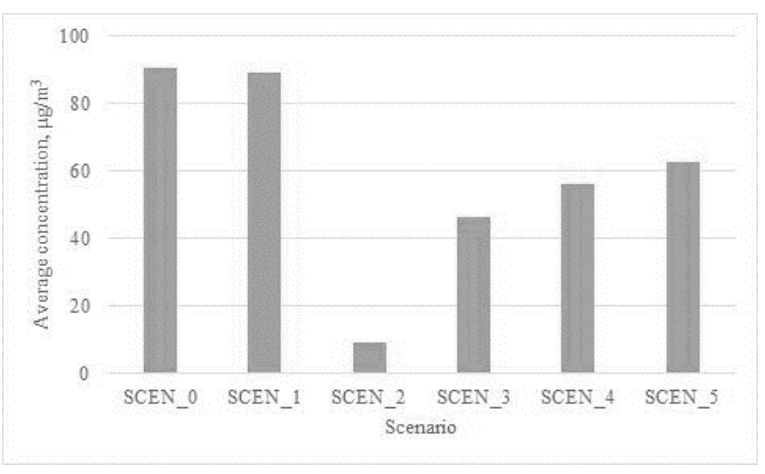

Fig. 5. Average modelled $\mathrm{NO}_{\mathrm{x}}$ concentration at receptor height $(2 \mathrm{~m})$ in street canyon

\section{CONCLUSIONS}

In this study, the OSPM scenario analysis methodology was used to predict pollutant levels in Riga city, thereby $\mathrm{NO}_{\mathrm{x}}$ and $\mathrm{PM}_{10}$ concentration levels in the street canyon were calculated for the zero scenario (real situation) and for five different possible development scenarios in order to introduce restrictions for traffic flow regimes.

Main conclusions are:

(1) traffic flow structural analysis show prevalence of light vehicles reaching at least $96-98 \%$ of total flow and $72 \%$ of these vehicles are 11 years old corresponding to EURO3 class;

(2) analysis of $\mathrm{PM}_{10}$ and $\mathrm{NO}_{\mathrm{x}}$ concentration variations show substantial weekly differences; as most polluted days were identified Wednesdays and Thursdays, while during holidays pollution levels are much lower; in case of $\mathrm{PM}_{10}$ concentration differences reach $12 \mu \mathrm{g} / \mathrm{m}^{3}$, but in case of $\mathrm{NO}_{\mathrm{x}}$ even $48 \mu \mathrm{g} / \mathrm{m}^{3}$ in average; 
(3) modelling results show that one of the most effective scenarios could be the scenario with restrictions for old cars when movement is allowed for EURO5 or higher standard light (passenger) cars; in this case effect for several cases could reach $9 \mu \mathrm{g} / \mathrm{m}^{3}$ for $\mathrm{PM}_{10}$ and $90 \mu \mathrm{g} / \mathrm{m}^{3}$ for $\mathrm{NO}_{\mathrm{x}}$ in average. As a less effective was identified the scenario with restrictions for a light vehicle (private car) flow during working days from 7:00 AM to 7:00 PM.

\section{ACKNOWLEDGEMENTS}

This study was supported by the Riga City research project DMV-17-60-1'-03.02.2017. The authors wish to thank the Riga City Council and Latvian Environment, Geology and Meteorology Centre for data used in this study.

\section{REFERENCES}

[1] United Nations, "World urbanization prospects: The 2014 Revision, Highlights," United Nations, Department of Economic and Social Affairs, Population Division, ST/ESA/SER.A/352, 2014 [Online]. Available: https://esa.un.org/unpd/wup/publications/ files/wup2014-highlights.pdf. [Acessed: Feb. 15, 2019].

[2] P. Kumar, M. de Fatima Andrade, R.Y. Ynoue, A. Fornaro, E.D. de Freitas, J. Martins, L.D. Martins, T. Albuquerque, Y. Zhang, L. Morawska, "New directions: from biofuels to wood stoves: the modern and ancient air quality challenges in the megacity of Sau Paulo," Atmos. Environ., vol. 140, pp. 364-369, 2016

[3] P. Kumar, M. Khare, R.M. Harrison, W.J. Bloss, A.C. Lewis, H. Coe, L. Morawska, "New directions: air pollution challenges for developing megacities like Delhi," Atmos. Environ., vol. 122, pp. 657-661, 2015.

[4] P. Kumar, S. Jain, B.R. Gurjar, P. Sharma, M. Khare, L. Morawska, R. Britter, "New Directions: can a "blue sky" return to Indian megacities?" Atmos. Environ., vol. 71, pp. 198-201, 2013.

[5] P.J. Irga, M.D. Burchett, F.R. Torpy, "Does urban forestry have a quantitative effect on ambient air quality in an urban environ- ment?” Atmos. Environ., vol. 120, pp. 173-181, 2015.

[6] J.A. Salmond, M. Tadaki, S. Vardoulakis, K. Arbuthnott, A. Coutts, M. Demuzere, K.N. Dirks, C. Heaviside, S. Lim, H. Macintyre, R.N. McInnes, B.W. Wheeler, "Health and climate related ecosystem services provided by street trees in the urban environment," Environ. Heal., vol. 15, pp. 95-111, 2016.

[7] K.V. Abhijith, Prashant Kumar, John Gallagher, Aonghus McNabola, Richard Baldauf, Francesco Pilla, Brian Broderick, Silvana Di Sabatino, Beatrice Pulvirenti. "Air pollution abatement performances of green infrastructure in open road and built-up street canyon environments - A review," Atmos. Environ., vol. 162, pp. 71-86, 2017

[8] S. Janhall, "Review on urban vegetation and particle air pollution - deposition and dispersion," Atmos. Environ., vol. 105, pp. 130-137, 2015

[9] F. Fantozzi, F. Monaci, T. Blanusa, R. Bargagli, "Spatio-temporal variations of ozone and nitrogen dioxide concentrations under urban trees and in a nearby open area," Urban Clim., vol. 12, pp. $119-127,2012$

[10] D. Chen, X. Wang, M. Thatcher, G. Barnett, A. Kachenko, R. Prince, "Urban vegetation for reducing heat related mortality," Environ. Pollut., vol. 192, pp. 275-284, 2014

[11] European Commission, "EMEP/EEA Air Pollutant Emission Inventory Guidebook". Technical Report No 9/2009.

[12] R. Berkowicz, "OSPM - a parameterised street pollution model," Environmental monitoring and assessment, vol. 65 (1-2), pp. 323 $331,2000$.

[13] National Environmental Research Institute, Denmark, Modelling traffic pollution in streets. Available: https://www.researchgate. net/publication/242294037_Modelling_traffic_pollution_in streets. [Accessed: October 25, 2018].

[14] National Environmental Research Institute, Denmark, "Modelling pollution from traffic in a street canyon. Evaluation of data and model development," [Online]. Available: https://www. researchgate.net/publication/279953823 Modelling_pollution from traffic in a street canyon Evaluation of data and model_development [Accessed: March 1, 2019].

[15] National Environmental Research Institute, Denmark, “Operational street pollution model (OSPM). Evaluation of the model on data from St. Olavs street in Oslo," [Online]. Available: https:// www.researchgate.net/publication/279953946 Operational Street_Pollution_Model_OSPM Evaluation_of the model_on data from St Olavs street in Oslo [Accessed: March 1, 2019]. 